\title{
Finfish Bycatch Diversity of Trawl Fishery of Nagapattinam Coast, Tamil Nadu, South India
}

\author{
S. Santhoshkumar ${ }^{1}$, P. Jawahar ${ }^{2}$, A. Srinivasan ${ }^{2}$, N. Jayakumar ${ }^{1}$, A. Subburaj ${ }^{1}$
}

10.18805/IJAR.B-4716

\begin{abstract}
Background: The present study was undertaken to analyse the monthly and seasonal finfish bycatch diversity of trawler fishery of Nagapattinam coast situated in the state of Tamil Nadu, South India from January 2017 to August 2019.

Methods: Samples of finfish bycatch were collected fortnightly from the commercial shrimp trawlers operating in the coastal waters off Nagapattinam. The collected bycatch of finfish species was identified and month-wise and season-wise trawl finfish bycatch occurrence data collected were subjected to univariate and multivariate analysis using PRIMER Version 6.1.7. software.

Result: In this study, the annual average total landing was estimated at $15,414.41$ tonnes with an annual average fishing effort of 9327 boat days. Of this total landing, commercial catch constituted $70.75 \%$ (10,905.78 tonnes), whereas finfish bycatch formed $21.12 \%(3,256.14$ tonnes $)$ and rest by other groups. The peak fishing effort was observed in every March during the study period. A total of 210 finfish species belonging to 15 orders, 79 families and 153 genera were recorded, in which the order, Perciformes alone shared $53.81 \%$ of the total number of species. The monthly univariate analysis revealed that bycatch diversity was the highest in every September and the lowest in every June during the study period, while the season-wise analysis revealed the highest diversity during monsoon seasons. Likewise, the month-wise multivariate analysis performed through cluster analysis divulged the highest similarity between September'17 and September'18, while the season-wise analysis revealed the highest similarity between postmonsoon'17 and postmonsoon'18. Further, the $\mathrm{K}$ dominance plot divulged that the highest density of finfish species was in every September and in monsoon seasons during the study period.
\end{abstract}

Key words: Bycatch, Diversity, Multivariate, Trawl, Univariate.

\section{INTRODUCTION}

Nagapattinam is blessed with a coastal length of $187.9 \mathrm{~km}$ which lies along the coast of Coromandel and Palk Bay on the shore of the Bay of Bengal, between the latitude of $10.7906^{\circ} \mathrm{N}$ and longitude of $79.8428^{\circ} \mathrm{E}$. Trawl is the dominant fishing gear operated by the trawling boats along the coast of Nagapattinam. Among 13 coastal districts of Tamil Nadu, Nagapattinam region contributed $13 \%$ of the total marine capture fisheries production next to Kanyakumari (28.4\%) and Ramanathapuram (20.8\%) regions during 2018 (CMFRI, 2019). The impact of rapid technological changes in fishery cannot be ignored. The increase in the catch along the Indian coast in the last two decades is essentially due to increase in efficiency of craft and gear and spatial extension of fishing to offshore regions. Mechanized and motorized boats have shown an incredible tendency to expand their engine power and also size in the recent times. Their unbridled expansion is a matter of serious concern for all and proper regulation of these boats is very important. Further, it is an alarming fact that bycatch is also increasing day by day. Bycatch is the major concern in the trawler fishery due to its nonselective nature. The changing perspective of bycatch itself offers the greatest challenge, as yesterday's bycatch becomes today's target catch (Boyce, 1996). Hence, efforts need to be taken to reduce the bycatch particularly the catch of juveniles and sub-adult fishes.

Though the studies on trawler bycatch were attempted by various researchers in India (Boopendranath, 2009;
1Dr. MGR Fisheries College and Research Institute, Tamil Nadu Dr. J. Jayalalithaa Fisheries University, Thalainayeru-614 712, Nagapattinam, Tamil Nadu, India.

${ }^{2}$ Tamil Nadu Dr. J. Jayalalithaa Fisheries University, Nagapattinam611 001, Tamil Nadu, India.

Corresponding Author: S. Santhoshkumar, Dr. MGR Fisheries College and Research Institute, Tamil Nadu Dr. J. Jayalalithaa Fisheries University, Thalainayeru-614 712, Nagapattinam, Tamil Nadu, India. Email: s.santhoshkumar@tnfu.ac.in

How to cite this article: Santhoshkumar, S., Jawahar, P., Srinivasan, A., Jayakumar, N., Subburaj, A. (2021). Finfish Bycatch Diversity of Trawl Fishery of Nagapattinam Coast, Tamil Nadu, South India. Indian Journal of Animal Research. DOI: 10.18805/ IJAR.B-4716.

Submitted: 12-07-2021 Accepted: 18-10-2021 Online: 22-12-2021

George et al., 1981; Gibinkumar and Boopendranath, 2008; Gordon, 1991; Kumar and Deepthi, 2006; Kurup et al., 2003; Pravin and Manohardoss, 1996; Rao, 1998; Sujatha, 1995, 1996 and 2005), studies on the trawler bycatch diversity in Tamil Nadu, particularly in Nagapattinam coastal area is very limited. In this context, the paper attempted to provide information on the diversity of trawl finfish bycatch along the Nagapattinam coast.

\section{MATERIALS AND MethodS}

Samples of finfish bycatch were collected from the commercial shrimp trawlers operating in the coastal waters 
off Nagapattinam from January 2017 to August 2019 (Fig 1). Trawlers operated in the Nagapattinam region have $18-20$ meters overall length $(\mathrm{OAL})$ and are made of steel. $A$ total of 430 registered trawlers are operated from Nagapattinam Fishing Harbour and have the fishing characteristics of multifleet, multi-day with multi-fishing gear fishery. The trawlers are operated at the depth of 15-90 $\mathrm{m}$ with a distance of 40-80 $\mathrm{nm}$ from the shore. The multiday fishing pattern usually operates 3 hauls/day and spends about 3-3.5 hours/haul, which are further subjected to various factors. Trawlers usually operate with a cod-end mesh size of $25 \mathrm{~mm}$. The bycatch finfish sampling was done fortnightly except during the trawl ban period i.e., from $15^{\text {th }}$ April to $14^{\text {th }}$ June. During sampling, the number of individuals of each finfish species was recorded and their weight was measured nearest to 1 gram. The bycatch of finfish species were identified based on the available taxonomic literature (Day, 1876; Lindberg, 1973; Fischer and Whitehead, 1974; Fischer and Bianchi, 1984; Gon and Randall, 2003). Month-wise and seasonwise trawl finfish bycatch data collected were subjected to univariate analysis to estimate the Shannon Weiner Diversity Index $\left(\mathrm{H}^{\prime}\right)$, Pielou's evenness $\left(\mathrm{J}^{\prime}\right)$, Species richness (S), Margalef's species richness (d), Taxonomic diversity $(\Delta)$ and Total phylogenetic diversity (sPhi+) in the finfish bycatch population using PRIMER Version 6.1.7 software. Multivariate analysis was employed to assess the similarities that exist in the distribution and abundance of the population during different months and seasons using cluster analysis and K-dominance plot from January 2017 to August 2019.

\section{RESULTS AND DISCUSSION}

The present study is based on the finfish catch and bycatch data collected from the commercial trawlers operated along the coast of Nagapattinam from January 2017 to August 2019.

\section{Estimated annual landings and finfish bycatch of trawl fishery}

The estimated annual average landing of trawl catch was $15,414.41$ tonnes with an annual average fishing effort of 9,327 boat-days. In the annual average landings, commercial catch shared $70.75 \%(10,905.78$ tonnes $)$ and annual finfish bycatch formed $21.12 \%(3,256.14$ tonnes). Furthermore, juveniles of finfish constituted $56.88 \%$ (1851.94 tonnes) of the annual bycatch landing. The peak fishing effort was observed in March 2017 (1975) followed by March 2019 (1694), March 2018 (1660) and it was observed to be the lowest in February 2018 (140), followed by September 2018 (192), September 2017 (207) with the fishing effort ranging from 140 (February 2018) to 1975 boat-days (March 2017) during the study period (Table 1) and monthwise estimated landing of total catch, commercial catch, finfish bycatch and low value juvenile finfish bycatch are illustrated in Fig 2 .

\section{Taxonomical identification of finfish bycatch}

Along the coast of Nagapattinam, 210 species of finfishes belonging to 15 orders, 79 families and 153 genera were collected from the bycatch of trawl fishing from January 2017 to August 2019. Finfish order-wise contribution of bycatch along the Nagapattinam region are showed in Fig 3 . Additionally, 12 species of deep-sea fishes such as Neoharriotta pinnata, Harpadon nehereus, Hoplostethus mediterraneus, Psenopsis cyanea, Neoepinnula orientalis, Lepidocybium flavobrunneum, Sphagemacrurus pumiliceps, Physiculus roseus, Alepocephalus bicolor, Lophiodes mutilus, Chascanopsetta lugubris and Ectreposebastes imus and 9 finfish species of rare groups including Mola mola, Bregmaceros mcclellandi, Atherinomorus lacunosus, Ptarmus jubatus, Satyrichthys laticeps, Pterygotrigla hemisticta, Opistognathus nigromarginatus, Bleekeria kallolepis and Bleekeria murtii were also recorded.

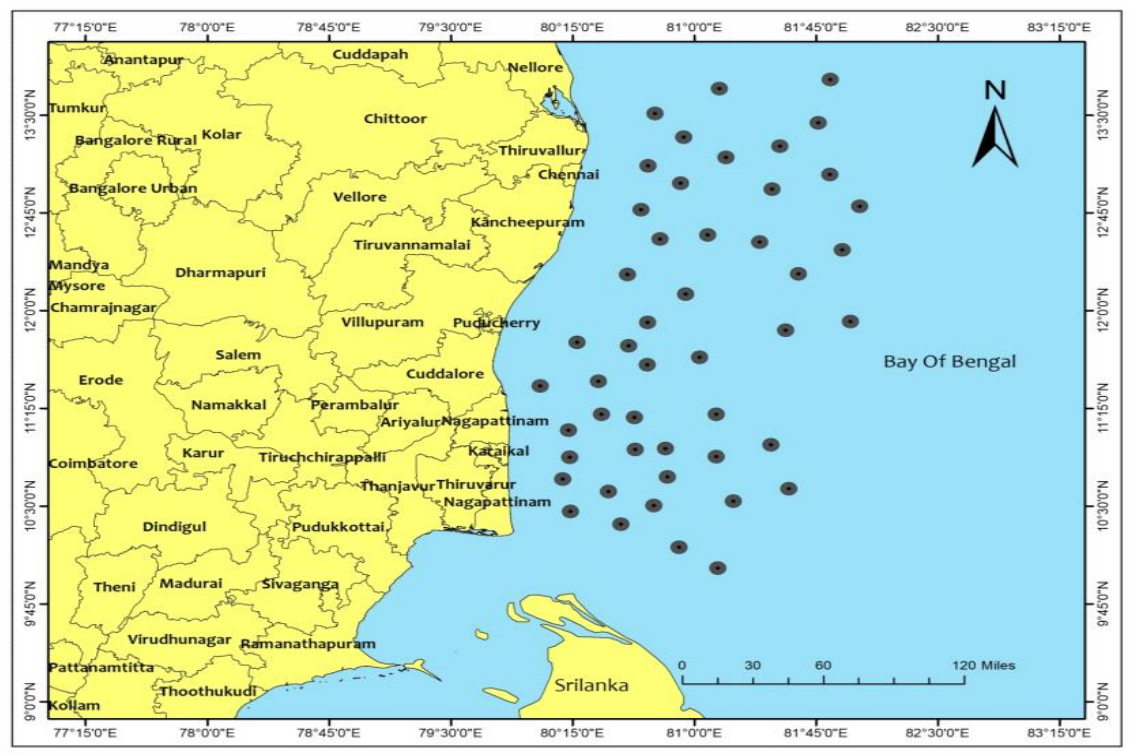

Fig 1: Trawling grounds of Nagapattinam coast. 


\section{Univariate analysis of monthly diversity}

Monthly values of species richness (S) was recorded maximum during September 2017 (134) and minimum during June 2018 (53) and Margalef's Species richness (d) value was recorded high in September 2017 (19.25) and low in June 2018 (8.18). The Species richness and diversity are indicative of the stability of a community, (2014). Shannon-Wiener's diversity index ( $\left.\mathrm{H}^{\prime}\right)$ was the highest in September 2017 (6.5479) and the lowest in June 2018 (4.9144). The range of the indices in the trawl fishing indicated the diverse nature of bycatch finfish species. Shannon Weiner Index (H') value was estimated to be low during June which may be due to the non-operation of trawlers due to trawl ban enforced between between $15^{\text {th }}$ April and $14^{\text {th }}$ June. During the study period, the $H^{\prime}$ value was found to be low during December 2017 (5.2870), followed by June 2018 (4.9144), January 2019 (5.2043) which may be due to the dominance of one or few finfish species (Clupeid group during December 2017, Leiognathid group during June 2018, grunters and Leiognathid groups during January 2019). Similar H'values of trawl finfish bycatch ranging from 5.6266 to 4.5265 (Kodeeswaran, 2019) and crustacean bycatch from 5.53 to 3.13 (Pillai, 2014) were reported along the Chennai Coast. Species evenness (J') value was found to be high in September 2018 (0.939) and low in June 2019 (0.852), revealing that finfish species were evenly distributed over the months and there was not much difference in the species distribution along the coast of Nagapattinam. It is a well-known fact that the species diversity is found maximum if all species are equally

Table 1: Estimated total catch, finfish bycatch, bycatch other than finfish and juvenile finfish catch of trawlers of Nagapattinam coast during Jan 2017- Aug 2019.

\begin{tabular}{|c|c|c|c|c|c|c|}
\hline $\begin{array}{l}\text { Month } \\
\text { of } \\
\text { sampling }\end{array}$ & $\begin{array}{c}\text { Total } \\
\text { effort } \\
\text { /month }\end{array}$ & $\begin{array}{l}\text { Estimated } \\
\text { total catch } \\
\text { (Tonnes) }\end{array}$ & $\begin{array}{c}\text { Estimated } \\
\text { commercial } \\
\text { catch (Tonnes) }\end{array}$ & $\begin{array}{c}\text { Estimated } \\
\text { finfish by } \\
\text { catch (Tonnes) }\end{array}$ & $\begin{array}{l}\text { Estimated by } \\
\text { catch other than } \\
\text { finfish (Tonnes) }\end{array}$ & $\begin{array}{l}\text { Low value } \\
\text { Juvenile } \\
\text { catch (Tonnes) }\end{array}$ \\
\hline Jan-2017 & 1290 & 1395.25 & 1018.53 & 255.89 & 120.83 & 99.09 \\
\hline Feb-2017 & 1260 & 1461.90 & 1081.81 & 305.83 & 74.26 & 130.27 \\
\hline Mar-2017 & 1975 & 1457.46 & 1020.22 & 326.32 & 110.91 & 131.12 \\
\hline Apr-2017 & 450 & 1113.83 & 846.51 & 212.41 & 54.91 & 91.50 \\
\hline Jun-2017 & 510 & 1155.30 & 820.26 & 236.84 & 98.20 & 172.65 \\
\hline Jul-2017 & 1209 & 1306.38 & 914.46 & 302.82 & 89.09 & 238.21 \\
\hline Aug-2017 & 1147 & 1279.72 & 857.41 & 321.59 & 100.71 & 221.03 \\
\hline Sep-2017 & 207 & 1223.43 & 868.64 & 267.81 & 86.99 & 130.30 \\
\hline Oct-2017 & 1200 & 1438.20 & 1035.50 & 311.37 & 91.33 & 162.37 \\
\hline Nov-2017 & 1110 & 1454.49 & 1018.15 & 334.53 & 101.81 & 160.62 \\
\hline Dec-2017 & 217 & 1525.59 & 1098.42 & 305.73 & 121.44 & 166.81 \\
\hline Jan-2018 & 279 & 1267.96 & 887.57 & 222.15 & 158.24 & 104.05 \\
\hline Feb-2018 & 140 & 1388.64 & 1013.71 & 275.23 & 99.70 & 123.24 \\
\hline Mar-2018 & 1660 & 1260.51 & 970.59 & 268.49 & 21.43 & 133.76 \\
\hline Apr-2018 & 420 & 1086.18 & 792.91 & 197.68 & 95.58 & 91.99 \\
\hline Jun-2018 & 510 & 1343.94 & 940.76 & 231.16 & 172.02 & 153.42 \\
\hline Jul-2018 & 1147 & 1884.80 & 1262.81 & 414.66 & 207.33 & 295.44 \\
\hline Aug-2018 & 1044 & 1656.83 & 1126.65 & 394.33 & 135.86 & 279.37 \\
\hline Sep-2018 & 192 & 1567.44 & 1050.18 & 319.76 & 197.50 & 232.98 \\
\hline Oct-2018 & 1248 & 1472.08 & 1030.46 & 348.59 & 93.04 & 213.04 \\
\hline Nov-2018 & 1080 & 742.00 & 504.56 & 152.85 & 84.59 & 88.53 \\
\hline Dec-2018 & 232 & 566.18 & 407.65 & 110.12 & 48.41 & 51.85 \\
\hline Jan-2019 & 783 & 1514.07 & 1090.13 & 290.70 & 133.24 & 123.07 \\
\hline Feb-2019 & 728 & 1520.60 & 1064.42 & 308.68 & 147.50 & 148.82 \\
\hline Mar-2019 & 1694 & 1538.57 & 1138.54 & 352.33 & 47.70 & 171.70 \\
\hline Apr-2019 & 390 & 1340.94 & 965.48 & 264.16 & 111.30 & 117.01 \\
\hline Jun-2019 & 255 & 1538.57 & 1030.84 & 280.02 & 227.71 & 183.36 \\
\hline Jul-2019 & 1110 & 1989.36 & 1412.44 & 493.36 & 83.55 & 344.80 \\
\hline Aug-2019 & 1102 & 2147.79 & 1481.97 & 478.96 & 186.86 & 321.98 \\
\hline Total & 24589 & 40638.01 & 28751.58 & 8584.37 & 3302.04 & 4882.38 \\
\hline $\begin{array}{l}\text { Annual average } \\
\text { with standard } \\
\text { deviation }\end{array}$ & $9327 \pm 517$ & $15414.41 \pm 316.26$ & $10905.78 \pm 215.34$ & $3256.14 \pm 83.69$ & $1252.50 \pm 49.60$ & $1851.94 \pm 74.36$ \\
\hline
\end{tabular}


abundant in the community. The Species richness (d) was found to be high in September 2017 (19.25) and low in June 2018 (8.18), giving an idea of variation in the species richness between different months during 2017-2019 in Nagapattinam coast. The species richness and evenness might be high and low in certain months which may be due to the migration of fish species influenced by the water temperature. When water temperature increases there is a coincidental increase in plankton biomass resulting in a high diversity level (Pillai, 2014). The monthly taxonomic diversity $(\Delta)$ was recorded high in August 2018 (92.99), followed by September 2017 (91.39) and low in June 2018 (77.86). The monthly total phylogenetic diversity was observed high in
September 2017 (7425) and low in June 2018 (3175). The values of taxonomic diversity and phylogenetic diversity are supportive and useful to understand the monthly diversity of finfish bycatch. The univariate analysis of monthly diversity is tabulated in Table 2.

\section{Multivariate analysis of monthly diversity}

The multivariate analysis performed through cluster analysis revealed the similarity in finfish bycatch diversity between months and seasons. Like-wise, the K-dominance plot was drawn used to illustrate the abundance of different finfish bycatch species in different months and seasons during the study period. The cluster analysis of trawl finfish bycatch

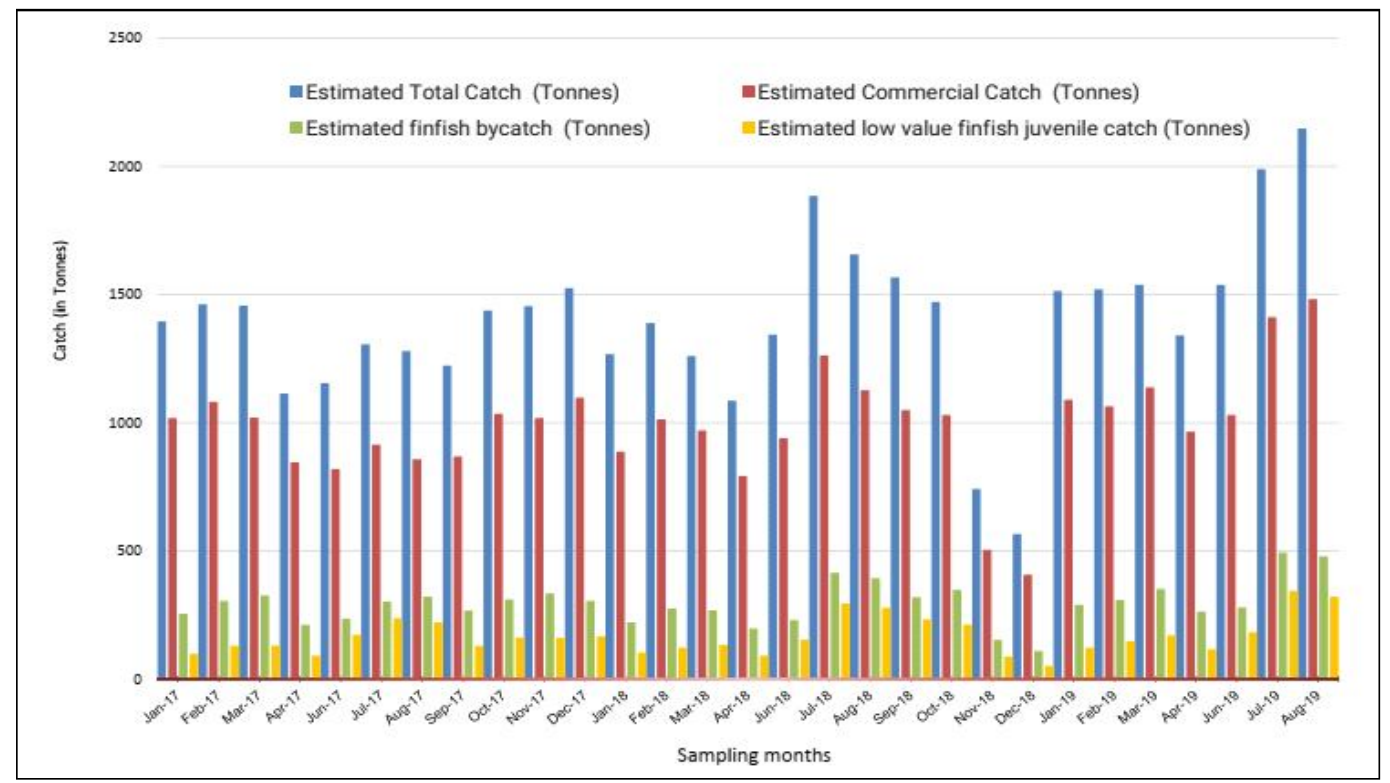

Fig 2: Estimated total catch, commercial catch, finfish bycatch and low value finfish juvenile catch of Nagapattinam coast.

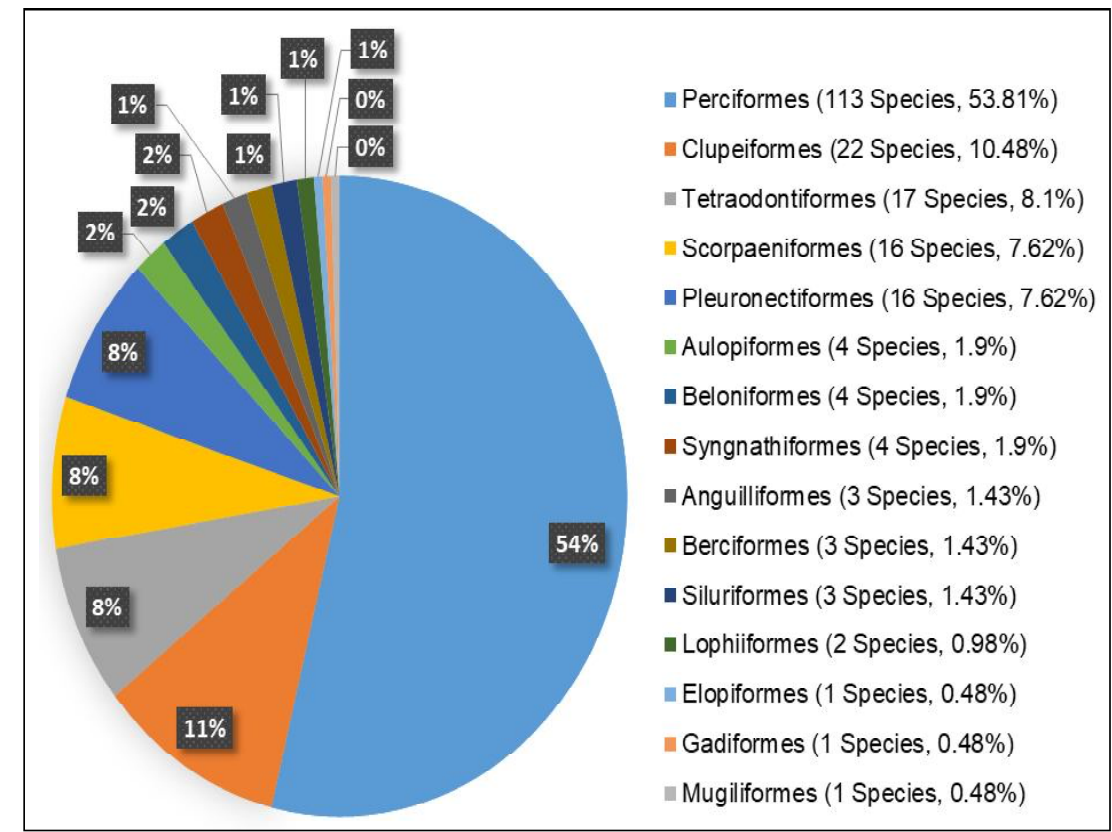

Fig 3: Finfish order-wise contribution of trawlers bycatch of Nagapattinam coast. 
showed the highest similarity $(66.68 \%)$ between September 2018 and September 2017 and the lowest similarity (30.21\%) between February 2019 and June 2018. The results of cluster analysis showed the presence of finfish species over different months (Fig 4). The study revealed that finfish bycatch landed in the trawl fishery of Nagapattinam coast are diverse in nature (6.5479-4.9144) and species assemblages are in a parallel manner across the months. The abundant diversity of bycatch species is a common phenomenon in trawler fisheries (Pillai, 2014; Saila, 1983).

The K-dominance curve was obtained by plotting percentage cumulative abundance against species rank $(K)$ on a logarithmic scale and the curve provides an undisturbed ecosystem exposed with an S-shaped curve. In the Nagapattinam coast, the plot showed that the curve for September 2017 and November 2018, which lie on the lower side, extended further and rose slowly due to the high intensity of species in this month. The dominance plot showed that the density of finfish bycatch species was high in September 2017 and November 2018 and proved that the number of species (richness) was more when compared to other months (Fig 5). Similar findings of abundant high diversity were observed along Chennai coast in December (Kodeeswaran, 2019), Thoothukudi coast in September (Ranjith, 2015) and Mangalore coast in October (Kumar et al., 2015; Sonwal et al., 2019).

\section{Univariate analysis of seasonal diversity}

A year was divided into four seasons namely summer (April, May, June), pre-monsoon (July, August, September), monsoon (October, November, December) and postmonsoon months (January, February, March) to assess the seasonal diversity (Pillai, 2014). Season-wise univariate analysis revealed that the species richness (S) ranged from 183 (monsoon 2017) to 123 (post-monsoon 2017) and Margalef's species richness (d) value ranged from 23.3575 (monsoon 2017) to 17.4877 (post-monsoon 2017). Similarly, species evenness $\left(\mathrm{J}^{\prime}\right)$ ranged from 0.9266 (monsoon 2018) to 0.8434 (premonsoon 2019). The estimated Shannon Weiner index was found to be within the range of 6.9241 (post-monsoon 2017) - 6.0386 (premonsoon 2019) whereas, taxonomic diversity $(\Delta)$ ranged from 90.92 (summer 2018) to 84.38 (post-monsoon 2019) and phylogenetic index ranged from 9775 (monsoon 2017) to 7025 (post-monsoon 2017). Upon comparing the different seasons of the study period, the monsoon seasons showed the maximum diversity (Table 3).

\section{Multivariate analysis of seasonal diversity}

The dendrogram of cluster analysis showed higher similarity (80.62\%) between postmonsoon seasons of 2017 and 2018 and lower similarity (49.21\%) between summer 2018 and monsoon 2019 (Fig 6). The seasonal K dominance curve indicated the high density of species during premonsoon 2017 and monsoon 2018 (Fig 7). In the present study, the highest seasonal similarity was found during post-monsoon, indicating that there was good recruitment to the fishery

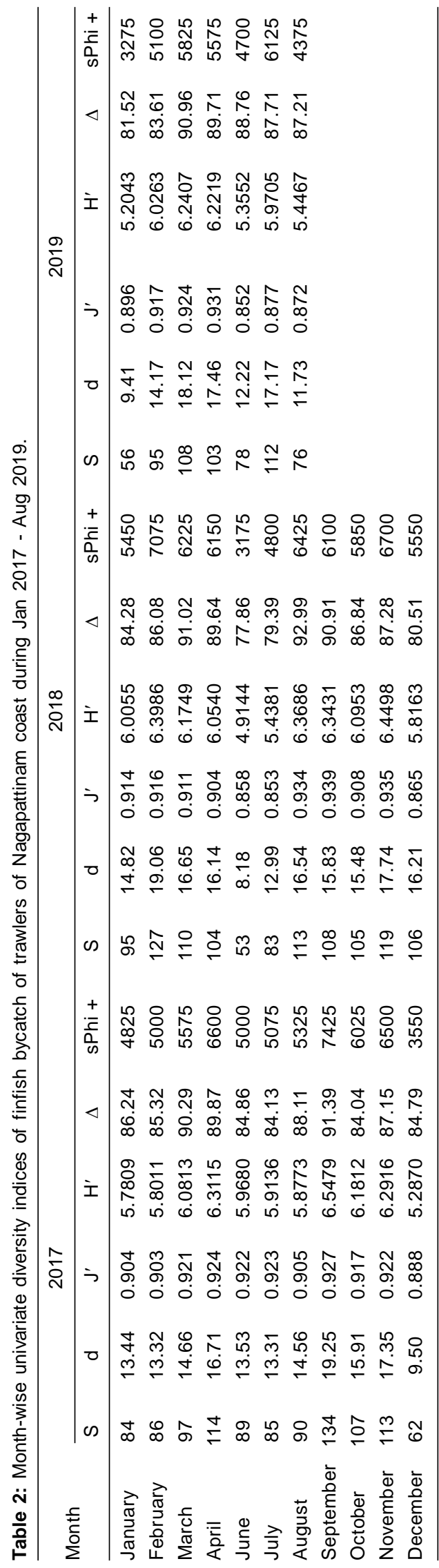


immediately after the monsoon season along the coast of Nagapattinam. The similarity findings of Nagapattinam region in the present study were in conformity with the findings of Kodeeswaran (2019), Purusothaman et al.
(2016), Kumar et al. (2015), Ranjith (2015), Karuppasamy et al. (2020) and Saroj et al. (2020). Additionally, high species abundance was reported in the premonsoon season which could be attributed to the trawl ban season.

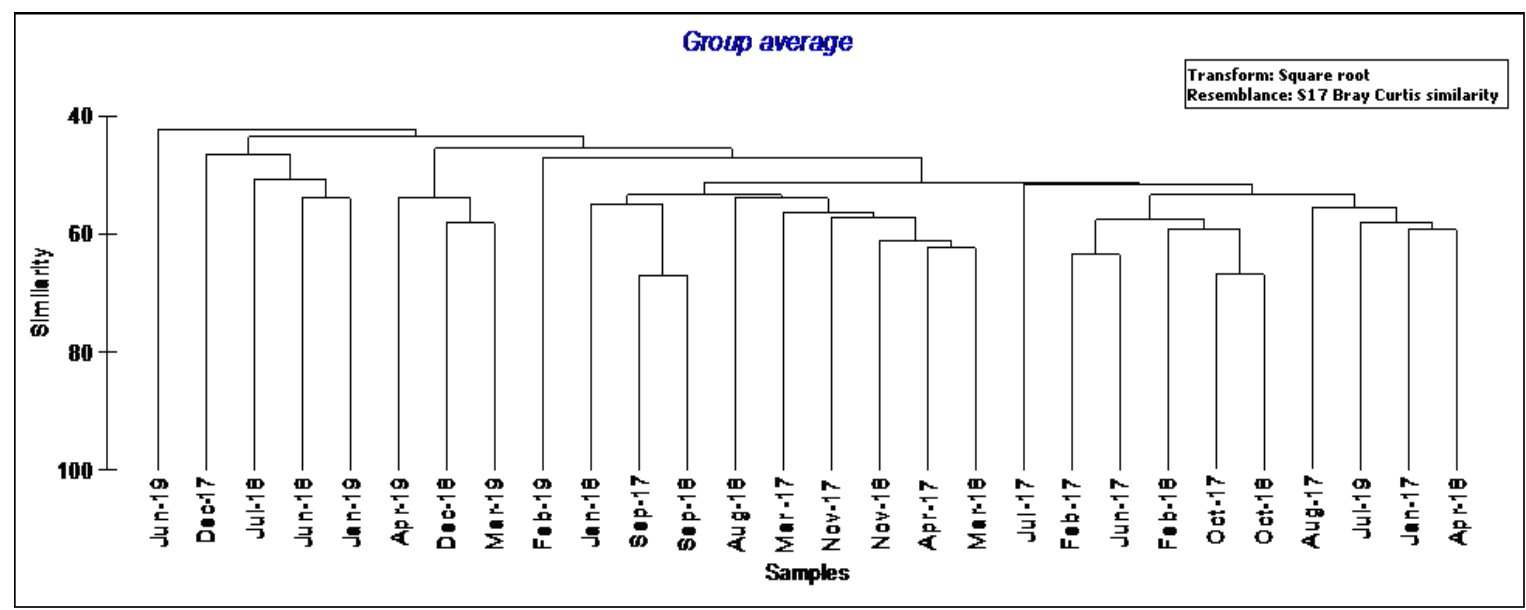

Fig 4: Month-wise dendrogram of finfish bycatch of trawlers of Nagapattinam coast from Jan'2017 to Aug'2019.

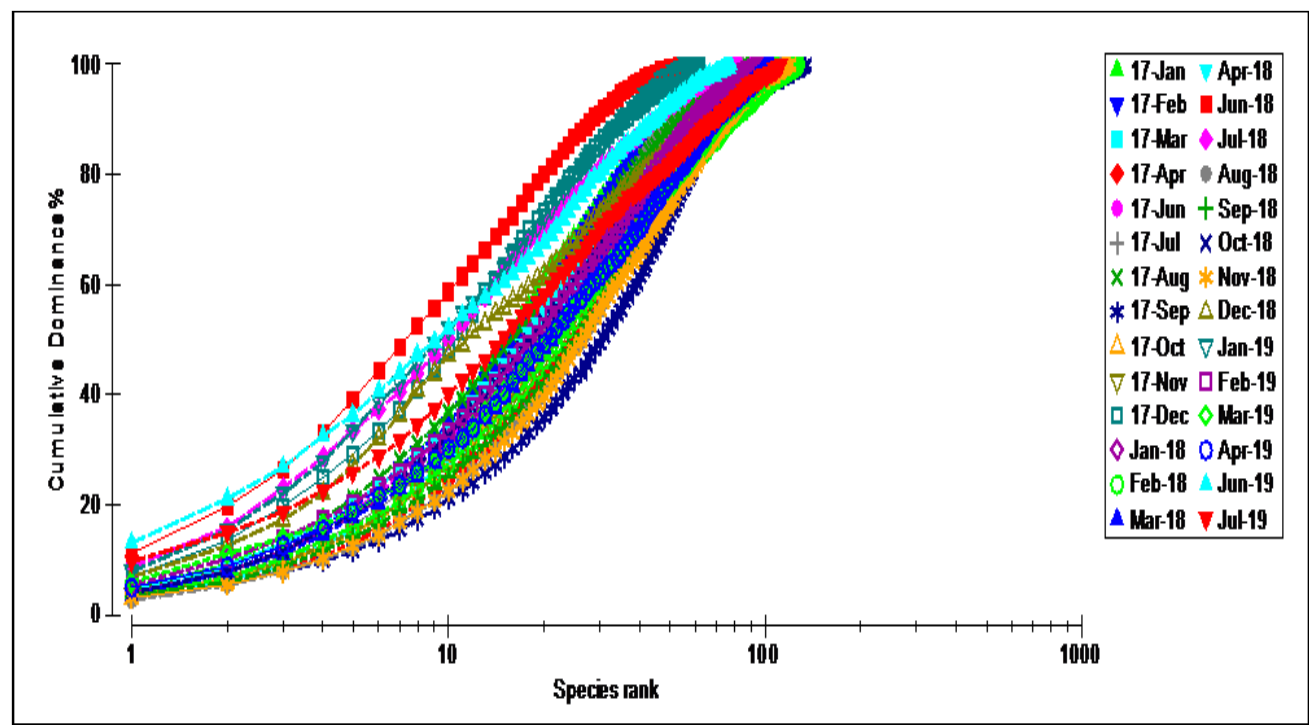

Fig 5: Month-wise K-dominance plot of finfish species bycatch of trawlers of Nagapattinam coast from Jan'2017 to Aug'2019.

Table 3: Season-wise univariate diversity indices of finfish bycatch of trawlers of Nagapattinam coast during Jan 2017-Aug 2019.

\begin{tabular}{lcccccc}
\hline Season & $\mathrm{S}$ & $\mathrm{d}$ & $\mathrm{J}^{\prime}$ & $\mathrm{H}^{\prime}$ & $\Delta$ & $\mathrm{sPhi+}$ \\
\hline Post monsoon 2017 & 123 & 17.4877 & 0.8876 & 6.1622 & 86.18 & 7025 \\
Summer 2017 & 148 & 19.9899 & 0.9096 & 6.5577 & 90.46 & 8200 \\
Pre monsoon 2017 & 145 & 19.4086 & 0.9007 & 6.4670 & 86.29 & 8125 \\
Monsoon 2017 & 183 & 23.3575 & 0.9213 & 6.9241 & 89.04 & 9775 \\
Post monsoon 2018 & 166 & 21.8162 & 0.8954 & 6.6037 & 86.67 & 8925 \\
Summer 2018 & 149 & 20.6702 & 0.8902 & 6.4264 & 90.92 & 8225 \\
Pre monsoon 2018 & 148 & 19.3347 & 0.8932 & 6.4395 & 87.90 & 8125 \\
Monsoon 2018 & 173 & 22.0243 & 0.9266 & 6.8893 & 89.56 & 9325 \\
Post monsoon 2019 & 150 & 19.9489 & 0.9091 & 6.5715 & 84.38 & 7875 \\
Summer 2019 & 144 & 21.7719 & 0.9207 & 6.6014 & 90.79 & 7700 \\
Pre monsoon 2019 & 143 & 18.9686 & 0.8434 & 6.0386 & 89.37 & 7850 \\
\hline
\end{tabular}




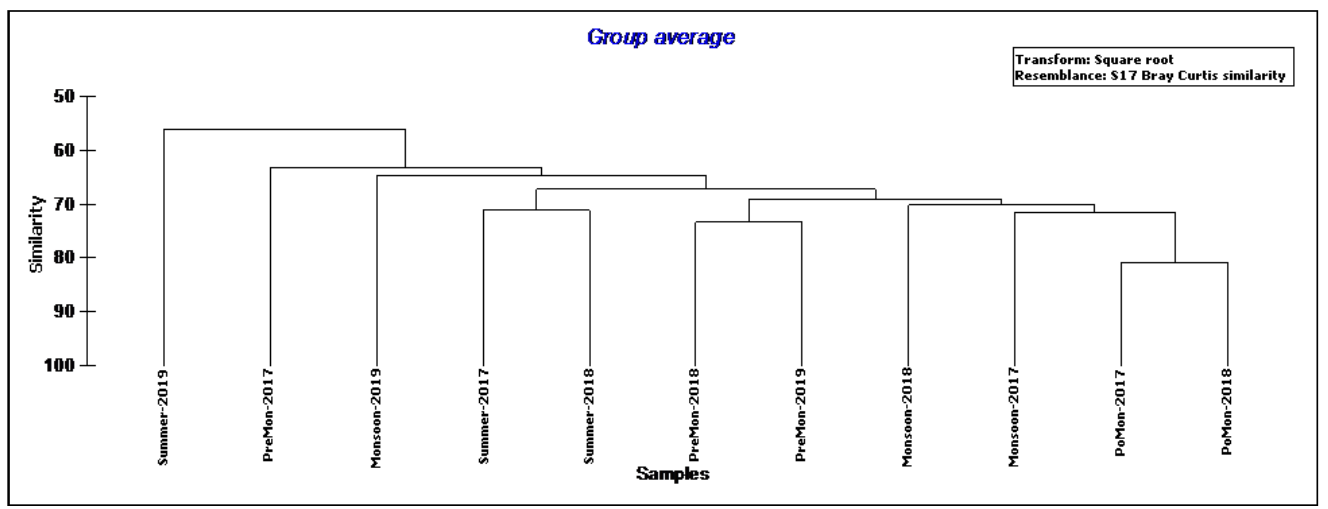

Fig 6: Season-wise dendrogram of finfish bycatch of trawlers of Nagapattinam coast from Jan'2017 to Aug'2019.

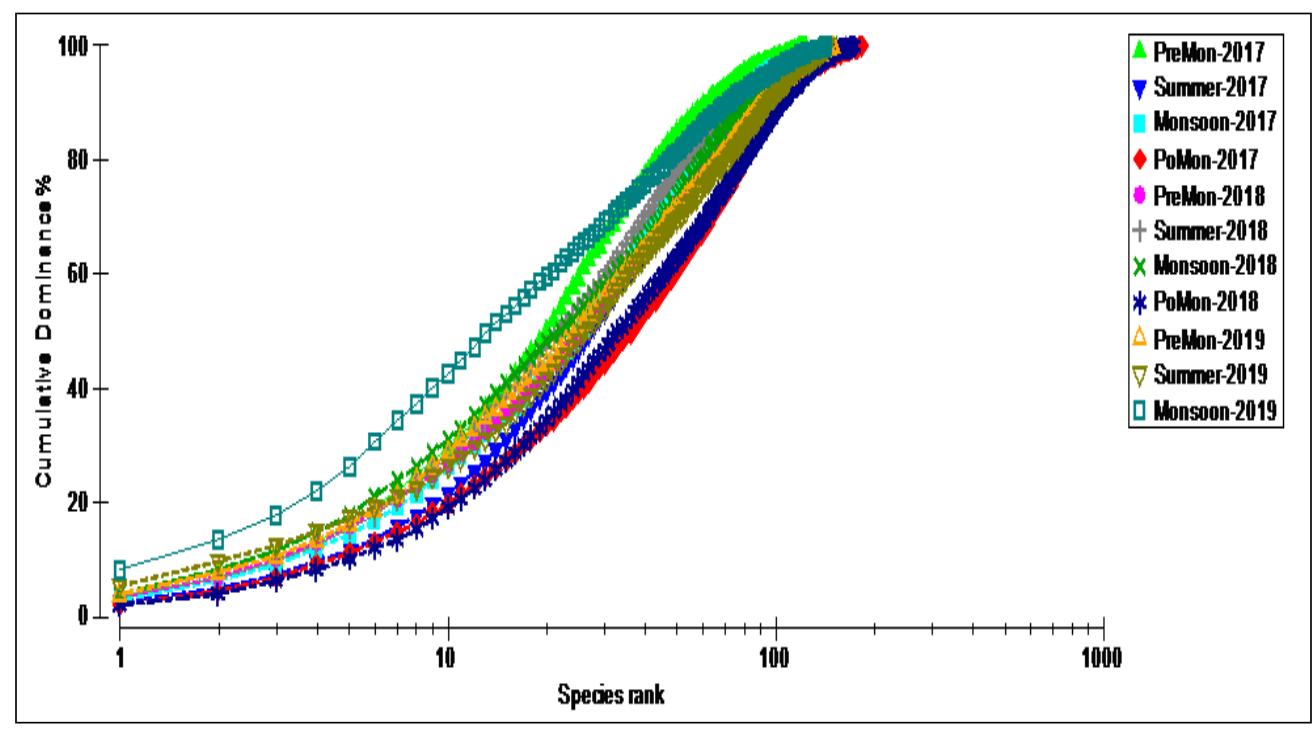

Fig 7: Season-wise K-dominance plot of finfish species of trawlers of Nagapattinam coast from Jan'2017 to Aug'2019.

\section{CONCLUSION}

Species diversity and abundance are indicators of a healthy ecosystem. In the present study, 210 species of finfish and 9 rare species of finfish were reported as trawl bycatch and the diversity was found to be high during monsoon season along the Nagapattinam coast. The species abundance and diversity indices provide baseline data information which will be very much useful for further studies on bycatch management in trawl fishery, impact of bottom trawling and conservation and management of fisheries resources along this coast.

\section{ACKNOWLEDGEMENT}

The authors express their deep sense of gratitude to the Vice-Chancellor, Tamil Nadu Dr. J. Jayalalithaa Fisheries University, Nagapattinam, Tamil Nadu, India for providing facilities and support to carry out the research.

\section{REFERENCES}

Boopendranath, M.R. (2009). Responsible Fishing Operations. Handbook of fishing Technology. Central Institute of Fisheries Technology, Cochin. 259-295.
Boyce, J.R. (1996). An economic analysis of the fisheries bycatch problem. Journal of Environmental Economics and Management. 31: 314-336.

Day, F. (1876). The Fishes of India: Being the natural history of the fishes known to inhabit the seas and fresh waters of India, Burma and Ceylon. (Issued in 4 Parts), London, Bernard Quaritch. 778.

Fischer, W. and Bianchi, G., (1984). Shrimps and Prawns: Families Alpheidae to Solenoceridae. In: FAO Species Identification Sheets for Fishery Purposes Western Indian Ocean Fishing Area No. 15, Volume 5. Rome: Food and Agricultural Organization.

Fischer, W. and Whitehead, P.J.P. (1974). FAO Species Identification Sheets for Fishery Purposes: Eastern Indian Ocean (Fishing Area 57) and Western Central Pacific (Fishing Area 71) Food and Agriculture Organization of the United Nations. vol. 2.

George, M.J., Suseelan, C., Balan, K. (1981). By-catch of the shrimp fishery in India. Marine fisheries information service, Technical and Extension Series. 28: 1-13.

Gibinkumar, T.R. and Boopendranath, M.R. (2008). Investigations on hard bycatchreduction devices for selective trawling. Ph.D. Thesis., Cochin University of Science and Technology, Cochin. 
Gon, O. and Randall, J.E. (2003). Revision of the Indo-Pacific cardinalfish genus Archamia (Perciformes: Apogonidae), with description of a new species (No. 35). Bishop Museum.

Gordon, A. (1991). The bycatch from Indian shrimp trawlers in the Bay of Bengal, Bay of Bengal Programme. The potential for its improved utilization. Working Paper No. 68, Bay of Bengal Programme, Chennai.

Karuppasamy, K., Jawahar, P., Kingston, S.D., Venkataramani, V.K. and Vidhya, V. (2020). Elasmobranch diversity, conservation and management along Wadge Bank, South India. Indian Journal of Animal Research. 54: 367-372.

Kodeeswaran, P. (2019). Assessment of fish bycatch of trawl net fishery of Chennai coast. M.F.Sc. Thesis, Tamil Nadu Dr. J. Jayalalithaa Fisheries University, Nagapattinam.

Kumar, A.B. and Deepthi, G.R. (2006). Trawling and by-catch: Implications on marine ecosystem. Current Science. 90: 922-931.

Kumar, J., Benakappa, S., Dineshbabu, A.P., Anjanayappa, H.N., Somashekara, S.R., Naik, K.A., Mahesh, V. (2015). Marine ichthyofaunal biodiversity in the trawling grounds off Mangalore coast. Indian Journal of Geo-Marine Science. 46: 879-885.

Kurup, B.M., Premlal, P., Thomas, J.V., Anand, V. (2003). Bottom trawl discards along Kerala coast: A case study. Journal of Marine Biological Association of India. 45: 99-107.

Linberg, G.U. (1973). Fishes of the World: A Key to Families and a Checklist (Original in Russian Published in 1971) New York. Halstead Press (English translation). Mercial Fisheries. FAO Fish. Circ. 765: 62.

Pillai, S.L., Kizhakudan, S.J., Radhakrishnan, E.V., Thirumilu, P., (2014). Crustacean bycatch from trawl fishery along north Tamil Nadu coast. Indian Journal of Fisheries. 61: 7-13.

Pravin, P. and Manohardoss, R.C. (1996). Constituents of low-value trawl by-catch caught off Veraval. Fishery Technology. 33: 121-123.
Purusothaman, S., Jayaprabha, N., Murugesan, P. (2016). Diversity and seasonal variation of fish assemblages associated with trawl catches from Southeast coast of India. Regional Studies in Marine Science. 6: 29-36.

Ranjith, L. (2015). A study on the species diversity of trawl bycatch along Thoothukudi coast and its economic valuation (Ph.D. Thesis), ICAR-Central Institute of Fisheries Education, Mumbai.

Rao, G.S. (1998). Bycatch and Discards of Shrimp Trawlers in Visakhapatnam. In: Symposium on Advances and Priorities in Fisheries Technology. Society of Fisheries Technologists India, Cochin. 501-505.

Saila, S.B. (1983). Importance and Assessment of Discards in Commercial Fsheries. FAO Fisheries Circular. 765. FAO, Rome: 62.

Saroj, J., Jawahar, P., Srinivasan, A., Neethiselvan, N., Jayakumar, N. (2020). Pelagic Fish Eggs Diversity in the Nearshore Waters of Gulf of Mannar, South East Coast of India. Indian Journal of Animal Research. 54: 1296-1303.

Sonwal, M.C., Somashekara, S.R., Anjanayappa, H.N., Umesh, S., Jitendra, K., Shobha, R., Gayatri, P. (2019). Marine crustaceans biodiversity in the trawling grounds off Mangalore coast, south-west coast of India. Journal of Experimental Zoology, India. 22: 1039-1044.

Sujatha, K. (1995). Finfish constituents of trawl bycatch off Visakhapatnam, Fishery Technology. 32: 56-60.

Sujatha, K. (1996). Trash fish catch of the trawl fishery off Visakhapatnam. J. Aquat. Biol. 11: 17-23.

Sujatha, K. (2005). Finfish Bycatch of Trawls and Trammel Nets off Visakhapatnam, Andhra Pradesh, In: [Boopendranath, M.R., Mathew, P.T., Gupta, S.S., Pravin, P. and Jeeva, J.C. (eds.)], Sustainable Fisheries Development - Focus on Andhra Pradesh, Society of Fisheries Technologists (India), Cochin, 87-94. 